\title{
Temperature influences swine wastewater treatment by aquatic plants
}

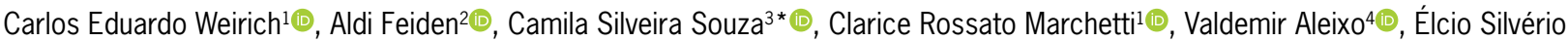 \\ Klosowskii]
}

\author{
'Universidade Federal de Mato Grosso do Sul/Instituto de \\ Biologia - Lab. de Ecologia, Av. Costa e Silva, s/n - 79070- \\ 900 - Campo Grande, MS - Brasil. \\ ¿Universidade Estadual do Oeste do Paraná - Lab. de \\ Agronomia, R. Pernambuco, 1777 - 85960-000 - Marechal \\ Rondon, PR - Brasil. \\ 3Universidade Federal do Paraná/Instituto de Biologia - \\ Depto. de Botânica, R. Elétrica, 540 - 82590-300 - Curitiba, \\ PR - Brasil. \\ 4Pontifícia Universidade Católica do Paraná - Lab. de \\ Ciências Ambientais, Av. da União, 500 - 85902-532 - \\ Toledo, PR - Brasil. \\ *Corresponding author <souza.camila.bio@gmail.com>
}

Edited by: Paulo Cesar Sentelhas

Received August 04, 2019

Accepted January 05, 2020
ABSTRACT: Studies show that aquatic plants are an efficient alternative to minimize the harmful effects of wastewater. Two species of aquatic macrophytes (Pistia stratiotes and Eichhornia crassipes) were chosen to evaluate the temperature effect on the performance of these macrophytes species in a post-treatment system of swine wastewater. The experiment was carried out in the municipality of Toledo, Paraná State, Brazil. For the experimental system, 24 concrete tanks with $80 \mathrm{~L}$ capacity were used, each measuring approximately $1.5 \mathrm{~m}$ in length, $0.25 \mathrm{~m}$ in width and $0.16 \mathrm{~m}$ deep. Wastewater characteristics and variables hydrogen potential $(\mathrm{pH})$, electrical conductivity (EC), and dissolved oxygen (DO) were measured weekly. After, we analyzed the aquatic macrophytes and centesimal composition. The use of aquatic macrophytes was efficient for final swine wastewater polishing. Nitrogen removal showed higher efficiency in the summer period for both species studied. The abiotic variables ( $\mathrm{pH}$ and EC) presented better results during the winter for both species evaluated. Air and wastewater low temperatures did not influence these variables. Dissolved oxygen presented better results in the summer period for $E$. crassipes species. There was a significant increase in $\mathrm{N}$ and $\mathrm{P}$ contents in the plant tissue. This fact proves that the use of aquatic macrophytes is an interesting alternative for swine wastewater treatment.

Keywords: Pistia stratiotes, Eichhornia crassipes, nitrogen, phosphorus, macrophytes

\section{Introduction}

In the last ten years, Brazil has increased its swine production by 3 million tons per year, reaching 3.75 million tons in 2017. Most production is consumed by the domestic market $(81.5 \%)$, and the states of Paraná, Santa Catarina, and Rio Grande do Sul account for $68.9 \%$ of pig slaughters in 2017 (ABPA, 2018). However, this practice is considered by environmental agencies as a potential source of contamination and degradation of air, water resources, and soil (Rasheed et al., 2018). Studies point to aquatic plants as an efficient alternative to mitigate the harmful effects of wastewater (Gomes et al., 2016). In phytoremediation, plants absorb water and nutrients, as well as pollutants, through their roots, acting as a biological filter. In this sense, the capacity of these plants can be enhanced with the application of species better adapted to bioaccumulation of specific pollutants (Dudai et al., 2018; Gajić et al., 2018). However, to improve the efficiency of aquatic macrophytes as a filter for wastewater, it is necessary to understand how some environmental factors can alter this efficiency. Temperature is one of the limiting factors that influences the primary productivity of macrophytes (Kirk, 1994), since it controls the speed of chemical reactions (Guo et al., 2019). Nevertheless, its ideal temperature range tends to vary among species and case studies are needed to better understand these dynamics (Geneviève et al., 1997).

In our study, we chose two species of aquatic macrophytes (Pistia stratiotes and Eichhornia crassipes) to evaluate the effect of temperature on the performance of these macrophytes species in a post-treatment system of swine wastewater. These species have been reported as efficient plants for treating wastewater and pollutants from different sources, such as aquaculture, industry, and domestic sewage (Henry-Silva et al., 2008; Shah et al., 2015). Sudiarto et al. (2019) conducted a study using swine effluent with different aquatic plants and found satisfactory results for the removal of total nitrogen (TN) and total phosphorus (TP). Xu and Shen (2011) and Muradov et al. (2014) also found positive results. During winter and summer, specifically, we attempted to answer the following questions: (i) How does temperature influence (in winter and summer) TN and TP removal from this wastewater by two species of macrophytes? (ii) How do the values of hydrogen ion concentration $(\mathrm{pH})$, electrical conductivity (EC), and dissolved oxygen (DO) vary during the study period (summer and winter)? (iii) How does biomass productivity of both species of macrophytes vary in different temperatures between the seasons? It is expected to find greater efficiency in TN and TP removal by macrophyte species. Moreover, it is expected to find higher biomass and values of electrical conductivity (EC) and dissolved oxygen (DO) in the summer (period with higher temperatures).

\section{Materials and Methods}

\section{Field station and experimental systems}

The experiment was carried out in the municipality of Toledo, Paraná State, Brazil $\left(24^{\circ} 40^{\prime} 57^{\prime \prime} \mathrm{S}, 53^{\circ} 49^{\prime} 25^{\prime \prime} \mathrm{W}\right.$, altitude of $760 \mathrm{~m}$ ). The study site was built with wooden beams and covered with transparent polyethylene (approximately $0.150 \mathrm{~mm}$ thick), preventing the entry 
of rain and allowing access to light (Figure 1A). The experiment was carried out in the summer (Feb and Mar) and winter (Aug and Sept) of 2008 (30 days for each experiment). For the experimental system, 24 concrete tanks with $80 \mathrm{~L}$ capacity were used, each measuring approximately $1.5 \mathrm{~m}$ long, $0.25 \mathrm{~m}$ wide, and $0.16 \mathrm{~m}$ deep. Each system comprised three tanks arranged at different height levels $(0.30 \mathrm{~m})$, totaling eight systems, with four of them for P. stratiotes and four for E. crassipes (Figures $1 \mathrm{~B}$ and $1 \mathrm{C})$. The system was operated in open circuit (continuous flow) and wastewater flowed through the three tanks by slope (gravity). Wastewater was stored in drums arranged above the tanks, where effluent was sent to the system continuously.

\section{Plant species}

Eichhornia crassipes (Mart. Solms) is native to the Amazon region. It has high growth rates and is considered a cosmopolitan plant (Chandra and Gerhardt, 2008). It can increase its green mass by $15 \%$ in a day, doubling it every six to seven days, under optimal condition, and producing up to 480 tons of green mass per hectare in a year (Barbieri and Esteves, 1991). E. crassipes presents better development in tropical climate and can survive low temperatures, even severe winters. Some factors, such as low light intensity, air temperatures between 26 and 30 ${ }^{\circ} \mathrm{C}$, long photoperiods and high plant density may promote anatomical modifications (Shu et al., 2014). The ideal water temperature for $E$. crassipes growth is between 28 and 30 ${ }^{\circ} \mathrm{C}$, while low air humidity from $15 \%$ to $40 \%$ may also be a limiting factor for the species growth (Jafari, 2010).

Pistia stratiotes is very common in lentic environments. It has a high potential for development in eutrophic environments and its growth is accelerated under the influence of light incidence in open environments (Farnese et al., 2014). It does not withstand cold or frost; however, its seeds survive freezing temperatures and prefer water with acid to neutral $\mathrm{pH}$ and organic background (Hall and Okali, 1974). Pistia stratiotes is a pioneer species, has good development with decomposed organic material, and can be considered an indicator of eutrophication. It is aggressive, fast-moving and thickens mainly in polluted, nutrient-rich water. It is considered a tropical and subtropical species. In Brazil, the species is abundant and widely distributed, both in natural aquatic ecosystems and in aquatic environments affected by anthropic activities (Pott and Pott, 2000). The ideal water temperature for $P$. stratiotes growth is around 15 to $35^{\circ} \mathrm{C}$ (Neuenschwander et al., 2009).

Studies published in 1975 and 1999, which used aquatic plants to treat water and effluents, pointed to the removal of $\mathrm{N}$ and $\mathrm{P}$ nutrients, followed by the removal of metals. These plants are known for their ability to accumulate pollutants, which may occur by physicochemical interaction or by mechanisms dependent on metabolism. The DO amount in the nearest plant layers is reduced, creating anaerobic conditions, maximizing nutrient removal (Azubuike et al., 2016).

\section{Wastewater characteristics and variables measurements}

The effluent used was prevenient from swine breeding in the municipality of Toledo $\left(24^{\circ} 40^{\prime} 57^{\prime \prime} \mathrm{S}\right.$, $53^{\circ} 49^{\prime} 25^{\prime \prime}$ W, altitude of $\left.760 \mathrm{~m}\right)$, Paraná State, Brazil. The system originates from the treatment of swine wastewater, known as Biosystem Integration (BSI). The BSI had two biodigesters, a sedimentation tank, two algae tanks, and a tank for pisciculture. The wastewater was collected in the algae rearing tank. After preliminary testing, the swine wastewater effluent was diluted 3:1 with rainwater collected and stored in $1000 \mathrm{~L}$ boxes nearby the experimental system, avoiding the phytotoxic effects on plant species, ensuring their survival.

Initial and final physical and chemical analyses of the wastewater performed in triplicate for each experimental system, in both study periods (summer and winter) following standard methods (APHA, 2005). The analysis of total nitrogen (TN) and total phosphorus
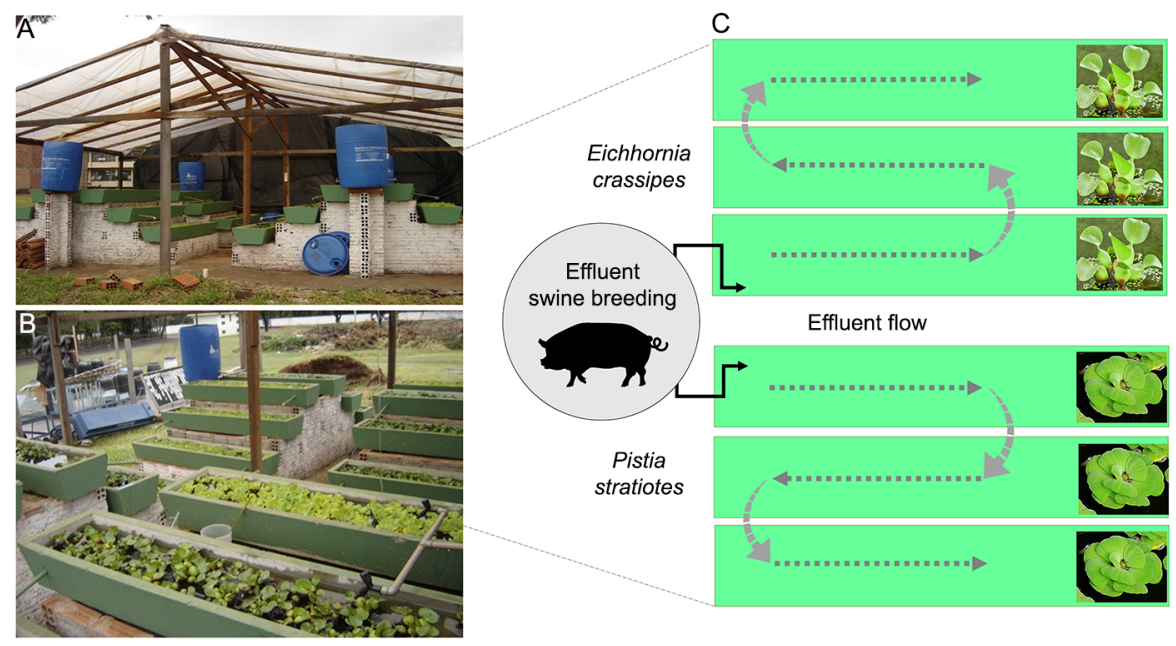

Figure 1 - A and B) Experiment figures and C) Scheme of the experimental system used in the study. 
(TP) was determined at the beginning and at the end of the experiments. We used the method of nitroperchloric digestion and sulfuric digestion following the methodology described by (Golterman et al., 1978). Hydrogen potential $(\mathrm{pH})$, electrical conductivity (EC), and dissolved oxygen (DO) were measured weekly. For $\mathrm{pH}$ determination, a digital $\mathrm{pH}$ meter was used. The amount of DO was determined by a portable oximeter and EC by a portable conductivity meter.

The air and effluent temperatures were measured at 8:00 a.m., 12:00 p.m., and 4:00 p.m. on each day of the experiment using mercury thermometers with scale from -10 to $+60^{\circ} \mathrm{C}$ and division of $1^{\circ} \mathrm{C}$. The minimum temperature recorded during the experimental periods was measured using a chapel type thermometer.

\section{Aquatic macrophytes and centesimal composition}

The aquatic macrophytes used were the Water hyacinth (Eichhornia crassipes (Mart.) Solms) and Water lettuce (Pistia stratiotes L.). The plants were collected at the Aquaculture Research Center - CPA (in the municipality of Toledo) and transported to the experiment site in water tanks to avoid water stress. Afterwards, the plants were deposited in 25,000-gallon tanks, remaining for 30 days for the biological adaptation of the species in the new environment (Espinoza-Quinonês et al., 2005). We evaluated some chemical properties of the plants before subjecting them to the treatment system. The analyses were repeated at the end of the experiment, according to the analytical standards of the Association of Official Analytical Chemists (AOAC, 2000). Three repetitions were made for each parameter. The methods used for the analysis were: percentage of crude protein $(\% \mathrm{CP})$ by the Kjeldahl method using the $\mathrm{N}$ transformation factor in protein of 6.25 , ref. 9402 (AOAC, 1996), humidity (\%) at $105^{\circ} \mathrm{C}$ until reaching constant weight, ref. 650.56 (AOAC, 1996), ash (\%) muffle incineration at $550{ }^{\circ} \mathrm{C}$, ref. 93808 (AOAC, 1996), nitrogen $(\mathrm{N})$ in Kjeldahl digestion (AOAC, 2000), and phosphorus (P) (Barbieri and Esteves, 1991) that were expressed as $\mathrm{g} \mathrm{kg}^{-1}$. Each concrete tank received $2.0 \mathrm{~kg}$ of plants, totaling 6.0 $\mathrm{kg}$ per system, which were removed from the $25 \mathrm{~m}^{3}$ water tank and deposited on a screen. Therefore, excess water was drained. After the experimental period, all plants were removed and weighed to obtain the total biomass gain.

\section{Statistical analysis}

The experimental design was completely randomized, composed of two species of macrophytes, arranged in four replications, and performed in two seasons (summer and winter). Data were submitted to analysis of variance (ANOVA) and t-test (parametric data). The Tukey test was applied when the ANOVA showed significant differences, always considering a level of significance of 5 $\%$ of probability. The PAST software version 3 was used for statistical analysis. For the statistical comparisons, it was evaluated if the temperature averages varied in relation to the season, then if this variation affected efficiency of aquatic macrophytes for $\mathrm{N}$ and $\mathrm{P}$ removal between seasons. Next, we compared the means of electric conductivity (EC) and dissolved oxygen (DO) between the seasons. Finally, we evaluated biomass gain of the aquatic macrophytes between the seasons and their chemical composition.

\section{Results}

The average air temperatures (minimum and maximum) differed significantly between the seasons (summer and winter), as well as the average wastewater temperature in the three evaluations $(p<0.05$; Figures 2A-C). Therefore, we evaluated the temperature effect on nitrogen (TN) and phosphorus (TP) removal by the aquatic macrophytes in the different seasons. In the initial condition, the wastewater had an average contents of $403.1 \mathrm{mg} \mathrm{L}^{-1}$ for NT and $54.4 \mathrm{mg} \mathrm{L}^{-1}$ for PT (Table 1). The results showed high efficiency in $\mathrm{TN}$ and $\mathrm{TP}$ removal by both species evaluated. The highest TN efficiency was observed in the summer, with $88 \%$ removal for Pistia stratiotes and $80 \%$ removal for Eichhornia crassipes. According to Tchobanoglous et al. (2003), this high removal percentage may also be related to the slight alkalinity observed in the effluent, as the $\mathrm{pH}$ was above 7, ammonium ions $\left(\mathrm{NH}_{4}^{+}\right)$can be volatilized as ammonia
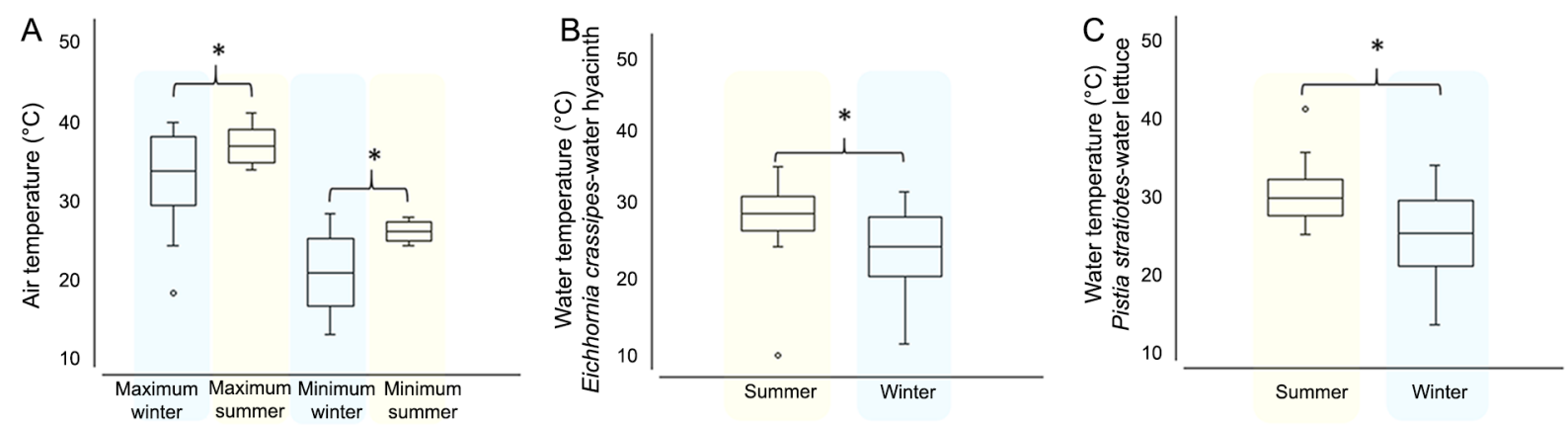

Figure 2 - A) Box plot (average and deviations) showing the variation in air temperature during the experiment period (summer and winter of 2008); B) Wastewater temperature of Eichhornia crassipes in summer and winter and C) Wastewater temperature of Pistia stratiotes in summer and winter. ${ }^{*}$ Indicates significant differences. ${ }^{*}$ Significant difference $(p \leq 0.05)$ between treatments during the summer and winter periods. 
$\left(\mathrm{NH}^{+}\right)$, contributing to TN removal of the effluent. For $\mathrm{TP}$, Eichhornia crassipes had greater removal in the winter (39 \%) differing from Pistia stratiotes, which had greater removal in the summer (38\%, Table 1$)$.

The $\mathrm{pH}, \mathrm{EC}$ and $\mathrm{DO}$ variables presented different results in relation to the initial wastewater values. The initial $\mathrm{pH}$ values were slightly alkaline /within the range 8.2), after the treatment with the aquatic macrophytes, the $\mathrm{pH}$ reduced significantly for both species $(p<0.05)$. Regarding the $\mathrm{pH}$ and the periods of evaluation, there was a significant difference between the summer and winter $(p$ $<0.05$, Table 2). The decrease in EC was also significant between treatments and evaluated periods, with better results for winter in both wastewater assessments (Table 2). Finally, DO contents presented an addition of $2.7 \mathrm{mg} \mathrm{L}^{-1}$ of DO in the summer, significantly different from the winter period for Eichhornia crassipes $(p<0.05)$. However, for Pistia stratiotes, the final DO values for winter and summer did not differ significantly. In relation to the chemical composition of the aquatic macrophytes, although some variables were significantly different between the periods of the experiment, in general, most analyzed variables in the aerial part (AP) and root (R) did not present significant differences between the periods studied (Table 3).

The initial weight of natural biomass for the treatments and year periods was $2.00 \mathrm{~kg} \mathrm{~m}^{-2}$ per tank, totalling $24 \mathrm{~kg} \mathrm{~m}^{-2}$ in each treatment system for each period. The final biomass production differed statistically $(p \leq 0.008)$ between the periods for the treatment with $E$. crassipes and did not present difference in the treatment with $P$. stratiotes. Biomass production for $E$. crassipes was $67.2 \%$ in the summer and $59.2 \%$ in the winter, while $P$. stratiotes presented biomass gain of $50 \%$ in the summer and $28.6 \%$ in the winter (Table 4).

\section{Discussion}

Air temperatures observed in this study showed that the plants remained for long periods under lower temperatures during the winter. Water temperature

Table 1 - Initial contents of the wastewater, average values, and standard deviation of the final contents and percentage (\%) of nitrogen (TN) and phosphorus (TP) removal by treatment systems with Eichhornia crassipes and Pistia stratiotes in the summer and winter periods.

\begin{tabular}{|c|c|c|c|c|c|c|}
\hline \multirow{2}{*}{\multicolumn{2}{|c|}{ Parameters }} & \multirow{3}{*}{$\begin{array}{c}\text { Initial wastewater } \\
403.1 \pm 22.3\end{array}$} & \multicolumn{2}{|c|}{ Eichhornia crassipes (water hyacinth) } & \multicolumn{2}{|c|}{ Pistia stratiotes (water lettuce) } \\
\hline & & & \multirow{2}{*}{$\begin{array}{l}\text { Summer final } \\
78.9 \pm 27.3^{*}\end{array}$} & \multirow{2}{*}{$\begin{array}{c}\text { Winter final } \\
156.7 \pm 69.8\end{array}$} & \multirow{2}{*}{$\begin{array}{l}\text { Summer final } \\
49.0 \pm 35.5^{*}\end{array}$} & \multirow{2}{*}{$\begin{array}{c}\text { Winter final } \\
191.9 \pm 68.1\end{array}$} \\
\hline NT & contents (mg L'-1) & & & & & \\
\hline & Removal (\%) & & $80 \pm 6.8$ & $61.1 \pm 17.3$ & $88 \pm 8.8$ & $52.4 \pm 17$ \\
\hline \multirow[t]{2}{*}{$\overline{\mathrm{PT}}$} & contents (mg L-1) & $61.23 \pm 4.8$ & $40.4 \pm 3.8^{*}$ & $37.5 \pm 3.2$ & $38.1 \pm 4.0$ & $39.3 \pm 0.7^{*}$ \\
\hline & Removal (\%) & & $34.1 \pm 6.2$ & $38.8 \pm 5.2$ & $37.6 \pm 6.3$ & $35.8 \pm 1.2$ \\
\hline
\end{tabular}

${ }^{*}$ Significant difference $(p \leq 0.05)$ between treatments during the summer and winter periods.

Table 2 - Average values and standard deviation of $\mathrm{pH}$, electrical conductivity (EC), and dissolved oxygen (DO) at the beginning and during the experimental phase (30 days) by the macrophytes in the summer and winter period.

\begin{tabular}{|c|c|c|c|c|c|c|c|c|c|}
\hline \multirow{2}{*}{ Treatment } & \multicolumn{3}{|c|}{$\mathrm{pH}$} & \multicolumn{3}{|c|}{$\mathrm{CE}\left(\mu \mathrm{S} \mathrm{cm^{-1 } )}\right.$} & \multicolumn{3}{|c|}{$\mathrm{DO}\left(\mathrm{mg} \mathrm{L}^{-1}\right)$} \\
\hline & Initial & Summer final & Winter final & Initial & Summer final & Winter final & Initial & Summer final & Winter final \\
\hline Eichhornia crassipes & $8.2 \pm 0.2$ & $7.6 \pm 0.3^{*}$ & $7.4 \pm 0.2$ & $2.6 \pm 0.5$ & $1.6 \pm 0.4^{*}$ & $1.3 \pm 0.5$ & $1.3 \pm 0.5$ & $4.0 \pm 1.4^{*}$ & $1.4 \pm 1.1$ \\
\hline Pistia stratiotes & $8.2 \pm 0.2$ & $7.7 \pm 0.3^{*}$ & $7.6 \pm 0.3$ & $2.6 \pm 0.5$ & $1.6 \pm 0.4^{*}$ & $1.4 \pm 0.5$ & $1.3 \pm 0.5$ & $2.8 \pm 1.3 \mathrm{~ns}$ & $1.4 \pm 1.0$ \\
\hline
\end{tabular}

${ }^{*}$ Significant difference $(p \leq 0.05)$ between treatments during the summer and winter periods. ns $=$ not significant.

Table 3 - Initial and final average and standard values of humidity, mineral matter, crude protein (CP), and macronutrients (phosphorus and nitrogen) in the total biomass (dry matter) in the aerial part (AP) and root (R) of Eichhornia crassipes and Pistia stratiotes periods of summer and winter.

\begin{tabular}{|c|c|c|c|c|c|c|}
\hline \multirow{3}{*}{ Parameters } & \multicolumn{6}{|c|}{ Treatment } \\
\hline & \multicolumn{3}{|c|}{ Eichhornia crassipes } & \multicolumn{3}{|c|}{ Pistia stratiotes } \\
\hline & Initial & Summer & Winter & Initial & Summer & Winter \\
\hline Humidity (AP) & $10.5 \pm 0.1$ & $8.6 \pm 1.5^{*}$ & $6.4 \pm 0.8$ & $11.7 \pm 0.1$ & $6 \pm 0.9 \mathrm{~ns}$ & $6.8 \pm 0.9$ \\
\hline Humidity (R) & $8.6 \pm 0.7$ & $4.7 \pm 0.7 \mathrm{~ns}$ & $5.7 \pm 0.8$ & $9.1 \pm 0.2$ & $4.7 \pm 1.3 \mathrm{~ns}$ & $4.9 \pm 0.6$ \\
\hline Crude protein (AP) & $17 \pm 3.5$ & $30.3 \pm 2.6 \mathrm{~ns}$ & $34.5 \pm 5.3$ & $11 \pm 1.8$ & $28.5 \pm 3.3 \mathrm{~ns}$ & $29.6 \pm 3$ \\
\hline Crude protein (R) & $12 \pm 2.3$ & $28.8 \pm 3.2^{*}$ & $24.4 \pm 3.8$ & $10 \pm 2.1$ & $25.3 \pm 2.2 \mathrm{~ns}$ & $26.5 \pm 5$ \\
\hline Ashes (AP) & $29.4 \pm 7.3$ & $18.9 \pm 2.5$ & $22.6 \pm 3.7^{*}$ & $22.8 \pm 2.9$ & $23.1 \pm 1.4 \mathrm{~ns}$ & $23 \pm 1.9$ \\
\hline Ashes (R) & $17.2 \pm 5.3$ & $16.2 \pm 2.6$ & $21.8 \pm 3.6^{*}$ & $22.3 \pm 2.1$ & $23.9 \pm 1.1$ & $27 \pm 3.8^{*}$ \\
\hline Phosphorus (AP) $\left(\mathrm{g} \mathrm{kg}^{-1}\right)$ & $14.9 \pm 0.2$ & $29.1 \pm 4.7$ & $50.5 \pm 6.6^{*}$ & $14.9 \pm 0.3$ & $26.8 \pm 6.5$ & $41.9 \pm 7.1^{*}$ \\
\hline Phosphorus (R) $\left(\mathrm{g} \mathrm{kg}^{-1}\right)$ & $16.5 \pm 0.5$ & $38.1 \pm 5.6 \mathrm{~ns}$ & $37.6 \pm 8.1$ & $18 \pm 0.6$ & $30.4 \pm 5.3$ & $40.4 \pm 7.6^{*}$ \\
\hline Nitrogen (AP) $\left(\mathrm{g} \mathrm{kg}^{-1}\right.$ ) & $13.4 \pm 1.5$ & $89.3 \pm 7.7^{*}$ & $38.9 \pm 3.1$ & $12.2 \pm 1.1$ & $85.8 \pm 6^{*}$ & $33.8 \pm 3.2$ \\
\hline Nitrogen (R) $\left(\mathrm{g} \mathrm{kg}^{-1}\right)$ & $15.3 \pm 1.6$ & $68.3 \pm 22.9^{*}$ & $26.4 \pm 3.8$ & $12.6 \pm 3.9$ & $65.6 \pm 13^{*}$ & $32.4 \pm 2.3$ \\
\hline
\end{tabular}

${ }^{*}$ Significant difference $(p \leq 0.05)$ between treatments during the summer and winter periods. ns $=$ not significant. 
Table 4 - Initial and average weight of the final biomass weight in the treatment systems with Eichhornia crassipes and Pistia stratiotes in the summer and winter periods. Average values and standard deviation of biomass produced, and daily biomass gain after 30 days of treatment.

\begin{tabular}{|c|c|c|c|c|}
\hline \multirow{3}{*}{ Parameters } & \multicolumn{4}{|c|}{ Treatment } \\
\hline & \multicolumn{2}{|c|}{ Eichhornia crassipes } & \multicolumn{2}{|c|}{ Pistia stratiotes } \\
\hline & Summer & Winter & Summer & Winter \\
\hline Initial weight (kg m²) & 2.00 & 2.00 & 2.00 & 2.00 \\
\hline Final weight $\left(\mathrm{kg} \mathrm{m}^{-2}\right)$ & 6.1 & 4.9 & 4.0 & 2.8 \\
\hline Biomass Production $\left(\mathrm{kg} \mathrm{m}^{-2}\right)$ & $4.1 \pm 1.6^{*}$ & $2.9 \pm 0.6$ & $2.0 \pm 1.4 \mathrm{~ns}$ & $0.8 \pm 1.1$ \\
\hline Daily biomass gain $\left(\mathrm{g} \mathrm{m}^{-2} \mathrm{~d}^{-1}\right)$ & $136 \pm 0.1^{*}$ & $95 \pm 0.02$ & $70 \pm 0.05^{*}$ & $25 \pm 0.04$ \\
\hline
\end{tabular}

${ }^{*}$ Significant difference $(p \leq 0.05)$ between treatments during the summer and winter periods. ns $=$ not significant.

was below the ideal range for $E$. crassipes and within the tolerable values for $P$. stratiotes. In this scenario, there was significant difference between the winter and summer in all the hours of the day when temperatures were measured. In relation to TN and TP removal, these components are responsible for eutrophication of water bodies (Mees et al., 2009). Nitrogen is involved in the formation of proteins, basic components of biomass. Under low concentrations, $\mathrm{N}$ may act as a limiting factor in the primary production of aquatic ecosystems (Feresin et al., 2010). Phosphorus can also act as a limiting factor in the primary production of aquatic ecosystems, leading to eutrophication. This fact may lead to changes in the physical, chemical, and biological properties of the environment, causing losses in productivity and biodiversity (Li et al., 2018; Mees et al., 2009).

The wastewater used in this research had high TN and TP contents, which are highly polluting if released directly into the environment. The aquatic plant species used in this research had a high potential for the removal of these nutrients, corroborating previous studies (González et al., 2009; Mees et al., 2009). According to Van de Moortel et al. (2010), N removal is more strongly influenced by season and temperature, because these factors affect mainly the activity of microorganisms. In our study, temperature had a direct influence on $\mathrm{N}$ absorption, since average air and water temperatures were lower in the winter. According to Mitsch and Gosselink, 1993, at low temperatures, biological processes slow down dramatically or cease. The presence of plants in humid areas results in more stable temperatures, which may promote the removal of pollutants (Hill and Payton, 2000). Some studies indicate a relationship between $\mathrm{N}$ and $\mathrm{P}$ contents in water and aquatic plants ( $\mathrm{Li}$ et al., 2018; Nogueira et al., 1996; Petracco, 1997). The high $\mathrm{N}$ and $\mathrm{P}$ contents in the wastewater are much higher than the values allowed by Res.357/05 - MMA (2005), which establishes values of $2.18 \mathrm{mg} \mathrm{L}^{-1}$ for $\mathrm{N}$ and 0.1 $\mathrm{mg} \mathrm{L}^{-1}$ for $\mathrm{P}$, when released in lotic environments. The biomass increase observed shows that this index, even high, did not prevent biomass accumulation, without interfering in the vegetative growth of the E. crassipes in the summer. Finally, regarding TN and TP removal, both macrophytes showed high efficiency in TN removal and accumulation of wastewater in both experiment periods. It is possibly related to the primary production and the high $\mathrm{N}$ contents in plants (Shah et al., 2015; Sooknah and Wilkie, 2004).

Both species of macrophytes used in this research were capable of reducing the $\mathrm{pH}$ values after the treatment in both periods evaluated. This reduction was expected due to the biochemical requirements related to the vegetative growth of macrophytes, which can modify the aquatic environment through oxidation of the rhizosphere, proton excretion $\left(\mathrm{H}^{+}\right)$, release of organic acids and carbon dioxide $\left(\mathrm{CO}_{2}\right)$ (Armstrong et al., 1990; Tanner et al., 1995; Coleman et al., 2001). The values found after the treatment by macrophytes in both periods were within the standards established by federal legislation, 6.0 to 9.0 Res. 357/05 - Brazil (2005). However, the EC levels observed in this study do not represent a risk for the growth of both macrophytes. The results indicate efficiency in reducing the EC in relation to the initial concentration, indicating a reduction in the availability of dissolved salts in the effluent. Regarding DO, several authors have reported that high water temperatures also reduce the capacity to keep DO at optimum levels (Ishida et al., 2006; Mamais and Jenkins, 1992).

In relation to the bromatological characteristics of macrophytes, after the treatment, there was an increase in their biomass for most parameters evaluated when compared to the initial values. Our results show that temperature influenced the moisture content in the samples of the aerial part of E. crassipes, presenting a higher percentage during the summer. Temperature had no influence on the tissues of $P$. stratiotes. This DM reduction in all treatments may be related to the high $\mathrm{N}$ contents in wastewater. Nitrogen is an important constituent of proteins and is directly related to increases in the primary production of aquatic macrophytes (Thomaz et al., 2006).

The percentage of crude protein (CP) was influenced by temperature in the root samples of $E$. crassipes during the summer. There was a significant difference in CP percentages in the summer when compared to the winter samples. Pistia stratiotes did not influence this variable when analyzed statistically between both periods. Eichhornia crassipes and $P$. stratiotes could be considered as plants with high protein content because they present CP values above $12 \%$ (Boyd, 1970). According to Henry-Silva et al. (2001), plants that store more minerals tend to contribute more directly to nutrient cycling. Thus, during the winter, 
when temperatures were lower, E. crassipes had a higher percentage of mineral matter in its tissues. Differently, for $P$. stratiotes, mineral matter was influenced only in the root samples. However, the mineral matter found in the biomass of aquatic macrophytes is one of the main limiting factors for its use as fodder. This high ash content tends to decrease OM content, reducing the nutritive value of these plants. Therefore, the lower the mineral content of a species, the greater its contribution in terms of OM production. Our results show that $E$. crassipes and $P$. stratiotes presented a high ash content.

\section{Conclusion}

The use of aquatic macrophytes were efficient for final swine wastewater polishing, since macrophytes showed efficiency in the removal of $\mathrm{N}$ and $\mathrm{P}$. The TN removal showed higher efficiency in the summer for both species studied. Eichhornia crassipes showed greater TP removal in the winter, different from the behavior presented by $P$. stratiotes. The abiotic variables, $\mathrm{pH}$ and EC presented better results during the winter, for both species and were not influenced by the low air and wastewater temperatures. Dissolved oxygen presented the best results in the summer for E. crassipes. The species studied showed a significant increase of $\mathrm{N}$ and $\mathrm{P}$ in plant tissue. The high $\mathrm{CP}$ levels found in the species studied indicate their high potential for use in animal feed and composting. Finally, in this study, E. crassipes was more efficient than $P$. stratiotes in the treatment of swine wastewater effluent.

\section{Acknowledgements}

To Jéssica Manfrin for help in the English language. The $1^{\text {st }}$ and $4^{\text {th }}$ authors thank the Coordination for the Improvement of Higher Level Personnel (CAPES) for grating the PhD scholarship and the $3^{\text {rd }}$ author was supported by CAPES through a post-doctoral scholarship (88887.318827/2019-00). This study was financed in part by the CAPES - Finance Code 001.

\section{Authors' Contributions}

Conceptualization: Weirich, C.E.; Feiden, A.; Klosowski, E.S.; Souza, C.S. Data acquisition: Weirich, C.E.; Feiden, A.; Klosowski, E.S. Data analysis: Weirich, C.E.; Souza, C.S. Design of methodology: Weirich, C.E.; Feiden, A.; Klosowski, E.S. Writing and editing: Weirich, C.E.; Feiden, A.; Klosowski, E.S.; Marchetti, C.R.; Aleixo, V.; Souza, C.S.

\section{References}

Armstrong, W.; Armstrong, J.; Beckett, P.M. 1990. Measurement and modelling of oxygen release from roots of Phragmites australis. p. 41-45. In: Cooper, P.F.; Findlater, B.C. (eds.). Constructed wetlands in water pollution control. Pergamon, Oxford, UK.
Associação Brasileira de Proteína Animal [ABPA]. 2018. Annual Report = Relatório Anual. ABPA, São Paulo, SP, Brazil. Available at: http://abpa-br.com.br/storage/files/relatorio-anual-2018.pdf [Accessed Jan 10, 2019] (in Portuguese)

Association of Official Analytical Chemists - International [AOAC]. 2000. Official Methods of Analysis. 16ed. AOAC, Washington, DC, USA.

Association of Official Analytical Chemists - International [AOAC]. 1996. Official Methods of Analysis. 2ed. AOAC, Washington, DC, USA.

American Public Health Association [APHA]. 2005. Standard Methods for the Examination of Water and Watewater. APHA, Washington, DC, USA.

Azubuike, C.C.; Chikere, C.B.; Okpokwasili, G.C. 2016. Bioremediation techniques: classification based on site of application: principles, advantages, limitations and prospects. World Journal of Microbiology and Biotechnology 32: 1-18. https://doi.org/10.1007/s11274-016-2137-x

Barbieri, R.; Esteves, F.A. 1991. The chemical composition of some aquatic macrophyte species and implications for the metabolism of a tropical lacustrine ecosystem Lobo Reservoir. Hydrobiologia 213: 133-140.

Boyd, C.E. 1970. Aminoacids protein and caloric content of aquatic macrophytes. Ecology 51: 902-906.

Chandra, S.; Gerhardt, A. 2008. Invasive species in aquatic ecosystems: issue of global concern. Aquatic Invasions 3: 1-2.

Coleman, J.; Hench, K.; Garbutt, K.; Sexstone, A.; Bissonnette, G.; Skousen, J. 2001. Treatment of domestic wastewater by three plant species in constructed wetlands. Water, Air, and Soil Pollution 128: 283-295.

Dudai, N.; Tsion, I.; Zemah S.S.; Nitzan, N.; Chaimovitsh, D.; Shachter, A.; Haim, A. 2018. Agronomic and economic evaluation of Vetiver grass (Vetiveria zizanioides L.) as means for phytoremediation of diesel polluted soils is Israel. Journal of Environmental Management 211: 247-255.

Espinoza-Quiñones, F.R.; Zacarkim, C.E.; Palacio, S.M.; Obregón, C.L.; Zenatti, D.C.; Galante, R.M.; Rossi, N.; Rossi, F.L.; Pereira, I.R.A.; Welter, R.A.; Rizzutto, M.A. 2005. Removal of heavy metal from polluted river water using aquatic macrophytes Salvinia sp. Brazilian Journal of Physics 35: 743-746.

Farnese, F.; Oliveira, J.; Lima, F.; Leão, G.; Gusman, G.; Silva, L. 2014. Evaluation of the potential of Pistia stratiotes L. (water lettuce) for bioindication and phytoremediation of aquatic environments contaminated with arsenic. Brazilian Journal of Biology 74: S108-S112.

Feresin, E.G.; Arcifa, M.S.; Silva, L.H.S. Esguícero, A.L.H. 2010. Primary productivity of the phytoplankton in a tropical Brazilian shallow lake: experiments in the lake and in mesocosms. Acta Limnologica Brasiliensia 22: 384-396.

Gajić, G.; Djurdjević, L.; Kostić, O.; Jaric, S.; Mitrović, M.; Pavlović, P. 2018. Ecological potential of plants for phytoremediation and ecorestoration of fly ash deposits and mine wastes. Frontiers in Environmental Science 6: 124.

Geneviève, M.C.; Duthie, H.C.; Taylor, W.D. 1997. Models of aquatic plant productivity: a review of the factors that influence growth. Aquatic Botany 59: 195-215.

Golterman, H.L.; Clymo, R.S.; Ohnstadt, A.M. 1978. Methods for chemical analysis of freshwater. Blackwell Scientific, London, UK. 
Gomes, M.A.; Hauser-Davis, R.A.; Souza, A.N.; Vitória, P. 2016. Metal phytoremediation: general strategies, genetically modified plants and applications in metal nanoparticle contamination. Ecotoxicology and Environmental Safety 134: 133-147.

González, F.; Vallejos, G.; Silveira, J.; Franco, C.; García, J.; Puigagut, J. 2009. Treatment of swine wastewater with subsurface-flow constructed wetlands in Yucatán, Mexico: influence of plant species and contact time. Water South Africa 35.

Guo, Z.; Sun, Y.; Pan, S.Y.; Chiang, P.C. 2019. Integration of green energy and advanced energy-efficient technologies for municipal wastewater treatment plants. International Journal of Environmental Research and Public Health 16: 1282.

Hall, J.B.; Okali, D.V.V. 1974. Phenology and productivity of Pistia stratiotes L. on the Volta lake, Ghana. The Journal of Applied Ecology 11: 709-725.

Henry-Silva, G.G.; Pezzato, M.M.; Benassi, R.E.; Camargo, A.F.M. 2001. Chemical composition of five species of aquatic macrophytes from lotic ecosystems of the southern coast of the state of São Paulo (Brazil). Acta Limnologica Brasiliensia 13: 11-17.

Henry-Silva, G.G.; Camargo, A.F.M.; Pezzato, M.M. 2008. Growth of free-floating aquatic macrophytes in different concentrations of nutrients. Hydrobiologia 610: 153-160.

Hill, D.T.; Payton, J.D. 2000. Effect of plant fill ratio on water temperature in constructed wetlands. Bioresource Technology 71: 283-289.

Ishida, C.K.; Kelly, J.J.; Gray, K.A. 2006. Effects of variable hydroperiods and water level fluctuations on denitrification capacity, nitrate removal, and benthic-microbial community structure in constructed wetlands. Ecological Engineering 28: 363373.

Jafari, N. 2010. Ecological and socio-economic utilization of water hyacinth (Eichhornia crassipes Mart Solms). Journal of Applied Sciences and Environmental Management 14: 43-49.

Kirk, J.T.O. 1994. Light and photosynthesis in aquatic ecosystems. Cambridge University Press, Cambridge, UK.

Li, W.; Li, Y.; Zhong, J.; Fu, H.; Tu, J.; Fan, H. 2018. Submerged macrophytes exhibit different phosphorus stoichiometric homeostasis. Frontiers in Plant Science 9: 1207.

Mamais, D.; Jenkins, D. 1992. The Effects of MCRT and temperature on enhanced biological phosphorus removal. Water Science and Technology 26: 955-965.

Mees, J.B.R.; Gomes, S.D.; Boas, M.A.V.; Fazolo, A.; Sampaio, S.C. 2009. Removal of organic matter and nutrients from slaughterhouse wastewater by using Eichhornia crassipes and evaluation of the generated biomass composting. Engenharia Agrícola 29: 466-473.

Ministério do Meio Ambiente [MMA]. 2005. National Council of Environment $=$ Conselho Nacional do Meio Ambiente. Resolution CONAMA $N^{\circ}$ 357, de 17/03/2005: It provides for the classification of water bodies and environmental guidelines for their framing, as well as the conditions and standards for the discharge of effluents, and other measures $=$ Dispõe sobre a classificação dos corpos de água e diretrizes ambientais para o seu enquadramento, bem como estabelece as condições e padrões de lançamento de efluentes, e dá outras providências. MMA, Brasília, DF, Brazil. Available at: http://www2.mma.gov.br/port/conama/legiabre.cfm?codlegi $=459$ [Accessed Mar 10, 2019] (in Portuguese).

Mitsch, W.J.; Gosselink, J.G. 1993. Wetlands. 2ed. John Wiley, New York, NY, USA.
Nogueira, F.; Esteves, F.A.; Prast, A.E. 1996. Nitrogen and phosphorus concentration of different structures of the aquatic macrophytes Eichhornia azurea Kunth and Scirpus cubensis Poepp \& Kunth in relation to water level variation in Lagoa Infernão (São Paulo, Brazil). Hydrobiologia 328: 199-205.

Muradov, N.; Taha, M.; Miranda, A.F.; Kadali, K.; Gujar, A.; Rochfort, S.; Stevenson, T.; Ball, A.S.; Mouradov, A. 2014. Dual application of duckweed and azolla plants for wastewater treatment and renewable fuels and petrochemicals production. Biotechnolology for Biofuels 7: 30.

Neuenschwander, P.; Julien, M.H.; Center, T.D.; Hill, M.P. 2009. Pistia stratiotes L. (Araceae). p. 332-352. In: Muniappan, R.; Reddy, G.V.; Raman, A., eds. Biological Control of tropical weeds using arthropods. Cambridge University Press, Cambridge, UK.

Petracco, P. 1997. Nitrogen reserves in Paspalum repens Berg. and Polygonum spectabile Mart., in Barra Bonita Reservoir - SP (Brazil). Internationale Vereinigung fur Theoretische and Limnologie: Verhandlungen 26: 581-583.

Pott, V.J.; Pott, A. 2000. Aquatic plants of the Pantanal = Plantas aquáticas do Pantanal. Embrapa-CPAP, Corumbá, MS, Brazil (in Portuguese).

Rasheed, T.; Bilal, M.; Nabeel, F; Adeel, M.; Iqbal, H.M.N. 2018. Environmentally-related contaminants of high concern: potential sources and analytical modalities for detection, quantification, and treatment. Environment International 122: 52-66.

Shah, M.; Hashmi, H.N.; Ghumman, A.R.; Zeeshan, M. 2015. Performance assessment of aquatic macrophytes for treatment of municipal wastewater. Journal of the South African Institution of Civil Engineering 57: 18-25.

Shu, X.; Zhang, Q.; Wang, W. 2014. Effects of temperature and light intensity on growth and physiology in purple root water hyacinth and common water hyacinth (Eichhornia crassipes). Environmental Science and Pollution Research 21: 12979-12988.

Sooknah, R.D.; Wilkie, A.C. 2004. Nutrient removal by floating aquatic macrophytes cultured in anaerobically disgested flushed dairy manure wastewater. Ecological Engineering 22: 27-42.

Sudiarto, S.I.A.; Renggaman, A.; Choi, H.L. 2019. Floating aquatic plants for total nitrogen and phosphorus removal from treated swine wastewater and their biomass characteristics. Journal of Environmental Management 231: 763-769.

Tanner, C.C.; Clayton, J.S.; Upsdell, M.P. 1995. Effect of loading rate and planting on treatment of dairy farm wastewaters in constructed wetlands. II. Removal of nitrogen and phosphorus. Water Research 29: 27-34.

Thomaz, S.M.; Pagioro, T.A.; Bini, L.M.; Murphy, K.L. 2006. Effects of reservoir drawdown on biomass of three species of aquatic macrophytes in a large sub-tropical reservoir (Itaipu, Brazil). Hydrobiologia 570: 53-59.

Tchobanoglous, G.; Burton, F.L.; Stensel, H.D. 2003. Wastewater Engineering: Treatment and Reuse. 4ed. McGraw-Hill, New York, NY, USA.

Van de Moortel, A.M.K.; Meers, E.; De Pauw, N.; Tack, F.M.G. 2010. Effects of vegetation, season and temperature on the removal of pollutants in experimental floating treatment wetlands. Water Air Soil Pollution 212: 281-297.

Xu, J.L.; Shen, G.X. 2011. Growing duckweed in swine wastewater for nutrient recovery and biomass production. Bioresource Technology 102: 848-853. 